\title{
PENDAMPINGAN BUDIDAYA JAMUR TIRAM SEBAGAI SARANA PEMBERDAYAAN EKONOMI UMAT DI KECAMATAN BANYUPUTIH KABUPATEN SITUBONDO
}

\author{
Ummal Khoiriyah \& Risma Fahrul Amin \\ Universitas Ibrahimy Situbondo, Indonesia \\ ummal2014@gmail.com \& rismafahrulamin@gmail.com
}

\begin{abstract}
The mosque is an instrument of empowering the people that has a very strategic role in efforts to improve the quality of society. Mosques are used as a center of activity in Islamic socitey. Since the time of the Prophet, the mosque has been a center for empowering the people that has had an unlimited role. This outreach program aims to assist the mosque management in Banyuputih District, Situbondo Regency in planning and designing programs to strengthen the function of mosques in the economic empowerment of the people.

From the results of this outreach program, it can be concluded that the efforts that had been made by mosque management in running a Mosque-Based Society Service Center was running a mushroom cultivation business which includes the production process, quality control, and marketing.
\end{abstract}

Keywords: Jamur Tiram, Pemberdayaan, Ekonomi Umat

\section{Pendahuluan}

Masjid adalah tempat ibadah sekaligus sebagai tempat untuk mengatur strategi perjuangan umat dalam rangka menetapkan pembinaan umat yang lebih efektif dan efisiensi.Disamping itu, masjid juga tempat mendekatkan diri dengan Khaliknya, tempat manusia

Vol. 2 No. 2, Oktober 2020
Ummal Khoiriyah \&

Risma fahrul Amin | 357

gurnal Pengabdian Masyarakat 
mengabdi dan bersujud kepada Maha Pencipta.Sesuai dengan makna harfiah dari kata masjid yaitu tempat shalat.Masjid merupakan instrumen pemberdayaan umat yang memiliki peranan sangat strategis dalam upaya peningkatan kualitas masyarakat.Namun hal itu harus didukung oleh menejemen pengelolaan masjid yang baik dan terpadu.

Dari segi bahasa, masjid berarti tempat untuk sujud atau untuk mengerjakan salat.Namun secara istilah berkembang sebagai tempat ibadah.Ibadah, diartikan sebagai pengabdian.Dengan demikian masjid berarti tempat pengabdian.Dalam perkembangan sejarah keberadaan dan fungsi masjid bukan saja untuk kepentingan melakukan ritual salat saja, tetapi juga untuk kepentingan-kepentingan lain yang bersifat sosial.Masjid dalam sejarah pendidikan Islam, telah berfungsi pula sebagai tempat atau media pendidikan.Masjid juga digunakan untuk pelayanan, penerimaan dan penyaluran zakat fitrah serta zakat maal.Kini masjid pun telah berkembang bahkan areanya berfungsi untuk pelayanan kesehatan (klinik kesehatan).Pada beberapa masjid besar juga dibangun kegiatan ekonomi dan koperasi.Oleh karena itu, kini masjid sekaligus menjadi kompleks Islamic Centre.

Menurut Nazarudin Umar ${ }^{1}$, Rasulullah saw tidak hanya menjadikan

${ }^{1}$ nasaruddinumar.org , masjid-dalam-sejarah-pembentukan-bangsaindonesia

Vol. 2 No. 2, Oktober 2020 Ummal Khoiriyah \& Risma fahrul Amin | 358 gurnal Pengabdian Masyarakat 
masjid sebagai tempat pelaksanaan ibadah khusus (mahdlah) seperti shalat, dsb., melainkan juga menjadi-kannya sebagai sarana melakukan pemberdayaan umat. Pada masa Rasulullah SAW, masjid juga dijadikan tempat untuk pembinaan penyebaran agama Islam, tempat mengobati orang sakit, tempat mendamaikan orang-orang yang bertikai, tempat untuk mengatur strategi dalam latihan perang, dan juga tempat untuk manyampaikan pengumuman penting. Hal tersebut tentunya dapat menjadi acuan pengembangan peran dan fungsi masjid khususnya dalam bidang pendidikan sesuai dengan perkembangan ilmu pengetahuan dan teknologi guna mewujudkan masyarakat yang berdaya dan mandiri.

Pengembangan peran dan fungsi masjid bidang pendidikan terasa semakin dibutuhkan mengingat semakin besar tantangan global yang berimbas pada moral dan karakter masyarakat sekarang ini.Karena masjid memiliki posisi sentral dalam menggerakkan masyarakat dalam isu-isu yang terkait dengan pembangunan moral dan karakter bangsa.Kredibilitas masjid hingga saat ini masih terpercaya sebagai lembaga sentral kehidupan keagamaan masyarakat.

Mengelola masjid pada saat ini perlu ilmu pengetahuan dan keterampilan.Pengurus masjid (takmir) harus mampu menyesuaikan diri dengan perubahan zaman. Di bawah sistem pengelolaan masjid Ummal Khoiriyah \& Risma fahrul Amin | 359 gurnal Pengabdian Masyarakat 
yang tradisional, umat Islam akan sangat sulit berkembang. Bukannya semakin maju, mereka malah akan tersingkir dan semakin jauh tertinggal oleh perputaran zaman. Masjid niscaya akan berada pada posisi yang stagnan, yang pada akhirnya bisa ditinggal oleh jamaahnya jika tidak kelola dengan baik. Pengurus masjid harus bekerjasama dengan baik dalam menjalankan roda kepengurusan dan perlu menerapkan manajemen masjid dan mekanisme kerja yang baik.Dengan adanya manajemen yang baik, modern, dan profesional maka pembinaan masjid dapat difungsikan secara maksimal. ${ }^{2}$

Pengelolaan masjid di Indonesia seyogyanya sejalan dengan pembangunan nasional Indonesia yang diarahkan pada konsentrasi meliputi: pertama, pro rakyat dalam bentuk penanggulangan kemiskinan berbasis keluarga, pemberdayaan masyarakat dan usaha mikro dan kecil; kedua, keadilan untuk semua meliputi keadilan untuk anak, perempuan, ketenaga-kerjaan, hukum serta kelompok miskin dan termarginalkan; ketiga, pencapaian tujuan milenium dengan delapan sasaran MDGs, terutama penuntasan kemiskinan. ${ }^{3}$

\section{Permasalahan dan Tujuan}

2 Tajuddin Hajma. Manajemen Kemasjidan, h.201

3 2010. “Instruksi Presiden Republik Indonesia No. 3 Tahun 2010 Tentang Program Pembangunan Yang Berkeadilan."

Vol. 2 No. 2, Oktober 2020
Ummal Khoiriyah \&

Risma fahrul Amin | 360

gurnal Pengabdian Masyarakat 
Permasalahan yang akan dibahas dalam pendampingan budidaya jamur tiramsebagai sarana pemberdayaan ekonomi umat ini yaitu bagaimanakah upaya takmir masjid dalam pemberdayaan ekonomi umat di Kecamatan Banyuputih, Kabupaten Situbondo?

Pengabdian kepada masyarakat ini bertujuan membantu dan mendampingi takmir Masjid di KecamatanBanyuputih, Kabupaten Situbondo dalammerencanakan, merancang program penguatan fungsi masjid dalam pemberdayaan ekonomi umat di Kecamatan Banyuputih, Kabupaten Situbondo.

\section{Signifikansi}

Masjid sebagai rumah ibadah bagi Muslimin dan Muslimat hadir bukan hanya sebagai pusat pengabdian manusia kepada Tuhan tetapi juga sebagai pusat pengabdian kepada masyarakat. Dengan kata lain, rumah ibadah bukan hanya tempat untuk melayani Tuhan tetapi juga untuk melayani manusia. Bahkan masjid di masa Nabi lebih sering digunakan sebagai pusat pelayanan pada masyarakat ketimbang tempat penyembahan terhadap Tuhan dalam arti ibadah mahdhah.

Salah satunya adalah Masjid Nabawi pada zaman Rasulullah digunakan untuk hal-hal yang kompleks pada masanya.Masjid Nabi digunakan sebagai tempat konsultasi Nabi dengan umatnya, baik konsultasi pribadi untuk masalah masalah-masalah kerumahtanggaan

Vol. 2 No. 2, Oktober 2020
Ummal Khoiriyah \&

Risma fahrul Amin | 361

gurnal Pengabdian Masyarakat 
maupun untuk masalah-masalah politik dan pemerintahan.Masjid Nabi juga digunakan sebagai tempat penyampaian informasi publik, misalnya untuk mengumumkan pernyataan publik Nabi, baik kapasitasnya sebagai Nabi/Rasul maupun dalam kapasitasnya sebagai kepala pemerintahan/negara.Maklum dahulu di zaman Nabi belum ada media efektif untuk menjangkau umat lebih luas selain masjid.

Masjid Nabi juga digunakan sebagai tempat untuk menyalurkan santunan sosial, misalnya sesama jama'ah mengumpulkan bantuan untuk jamaah lain yang kurang mampu. Zakat, shadaqah, infaq, jariyah, hibah, hadiah dan bantuan lainnya disalurkan kepada masyarakat yang berhak mrelalui mesjid. Di masjid Nabi ada gudang pangan yang pertanggung jawabannya diserahkan kepada Abi Hurairah, tersimpan di samping Bait Ahl al-Shuffah, tempat hunian Abu Hurairah dan kawan-kawan yang juga sekaligus bertugas memelihara kebersihan dan ketertiban masjid.

Masjid Nabi digunakan untuk mengontrol kondisi dan keadaan umat.Baik secara perseorangan maupun kolektif.Orang yang sakit perut bisa terdeteksi di masjid.Jika tiba-tiba jamaah Nabi tidak hadir tanpa ada laporan dipertanyakan kepada tetangganya. Kalau ketahuan sakit maka jamaah lain menziarahinya. Jika ada anggota jamaah masjid absen maka satu sama lain mempertanyakan keberadaan dan keadaannya.

Vol. 2 No. 2, Oktober 2020
Ummal Khoiriyah \&

Risma fahrul Amin | 362

gurnal Pengabdian Masyarakat 
Jika mereka sedang kesulitan maka jamaah masjid bergotong-royong membantunya.Luar biasa mesjid Nabi sebagai perekat umat dan warga masyarakat.

Manajemen masjid Nabi untuk ukuran zamannya bisa dianggap sangat moderen.Bayangkan masjid seperti itu sudah bisa menyelenggarakan sesuatu yang besar.Kota Madinah yang relatif kecil tetapi dipadati oleh pengungsi dari mana-mana mengikuti Nabi. Bukan hanya kaum muhajirin dari Mekkah tetapi dari etnik dan suku lain. Meskipun demikian Madinah tetap bertahan, khususnya masjid Nabi tidak tidak pernah menolak para pengungsi, selalu ada saja jalan keluar, meskipun Nabi sendiri harus menjalani kehidupan sederhana, bahkan sangat sederhana. Kulit belakangnya sering kelihatan bekas tikar kasar, jauh dari kasur yang empuk.Padahal beliau adalah bukan hanya Nabi dan Rasul tetapi juga kepala negara Madinah.

Kehadiran masjid Nabi betul-betul sebagai solusi dari berbagai persoalah umat dan warga Madinah tanpa membedakan agama dan etnik. Yang dibantu Nabi, bukan hanya umat Islam tetapi juga umat lain. Suatu ketika ada umat Nashrani tidak memiliki rumah ibadah, sementara mereka sangat membutuhkannya, maka Nabi menghimbau agar umat Islam yang memiliki kemampuan agar membantu membangunkan gereja dengan cara hibah, bukan wakaf atau jariyah.

Vol. 2 No. 2, Oktober 2020
Ummal Khoiriyah \&

Risma fahrul Amin | 363

gurnal Pengabdian Masyarakat 
Sampai sedemikian itu Nabi menyayangi warganya, sekalipun berbeda agama.

Masjid juga menjadi sarana yang optimal untuk pendampingan dan pemberdayaan masyarakat, karena Masjid memiliki magnet yang luar biasa untuk menyatukan kekompakan dan kegotong royongan masyarakat, sehingga dengan penguatan fungsi masjid maka akan berdampak pada masyarakat sekitar masjid.

\section{Gambaran Umum Lokasi Pendampingan}

Gambaran umum kondisi subyek dampingan, bahwa Kabupaten Situbondo merupakan salah satu daerah miskin di Propinsi Jawa Timur karena pendapatan asli daerah yang rendah dan banyak penduduk yang hidup dibawah garis kemiskinan.Pada tahun 2001 jumlah penduduk miskin adalah 173.357 jiwa. Jumlah tersebut pada tahun 2004 mengalami peningkatan menjadi 177.624 jiwa atau mengalami kenaikan 2,46\%. Hal itu disebabkan oleh kondisi perekonomian yang belum sepenuhnya kembali normal. Dari total jumlah, pada umumnya mereka mendiami wilayah Kecamatan Mangaran (28,93\%), Kapongan (32,28\%), Asembagus (23,23\%), dan Banyuputih (9,86\%). (Data Kemiskinan Kabupaten Situbondo, BPS: 904).

Situbondo dikenal sebagai kota santri, sehingga sendi kehidupan masyarakat Situbondo tidak terlepas dari peranan ulama maupun

Vol. 2 No. 2, Oktober 2020
Ummal Khoiriyah \&

Risma fahrul Amin | 364

gurnal Pengabdian Masyarakat 
asatid. Kondisi ini memberikan peluang bagi dosen Universitas IbrahimySitubondo untuk melaksanakan pengabdian. Sebagai bahan pertimbangan dilingkungan Kabupaten Situbondo berdasarkan informasi dari Kepala Bagian Sosial Pemkab Situbondo dan Kasi Urais Kementerian Agama Kabupaten Situbondo terdapat 456 Masjid Jamik dan 1356 Musholla yang tersebar di 14 Kecamatan.

Secara lebih spesifikbeberapa alasan yang melatarbelakangi Kecamatan Banyuputih dijadikan sebagai wilayah dampingan antara lain,merupakan kecamatan dengan wilayah terluas di Kabupaten Situbondo; memiliki jumlah masjid dan mushalla terbanyak diantara 16 kecamatan lainnya, yaitu masjid sebanyak 28 unit, mushalla sebanyak 114 unit, dan surau sebanyak 90 unit; terdapat 9 pondok pesantren di wilayah kecamatan Banyuputih; memiliki 99\% penduduk beragama Islam;lembaga pendidikan di wilayah kecamatan Banyuputih lengkap dari PAUD, TK, SD, SMP, SMU/SMK, sampai dengan Perguruan Tinggi; merupakan daerah binaan Universitas Ibrahimy.

\section{Kondisi saat ini Masyarakat Pendampingan}

Kecamatan Banyuputih merupakan wilayah administrasi dari Kabupaten Situbondo yang terletak sekitar $38 \mathrm{Km}$ kearah timur dari pusat pemerintahan, dan memiliki batas-batas yaitu: sebelah timur berbatasan dengan Selat Bali, sebelah selatan berbatasan dengan

Vol. 2 No. 2, Oktober 2020
Ummal Khoiriyah \&

Risma fahrul Amin | 365

gurnal Pengabdian Masyarakat 
Kabupaten Banyuwangi, sebelah utara berbatasan dengan Selat Madura, dan Sebelah barat berbatasan dengan Kecamatan Asembagus. Luas Kecamatan Banyuputih adalah $481.670 \mathrm{Km}^{2}$ atau $48.167 \mathrm{Ha}$. Terdiri atas 5 (lima) desa yang memiliki pantai dan sebagian besar wilayah Kecamatan Banyuputih merupakan tanah datar dengan 29 dusun, 56 RW, dan 172 RT.

Wilayah Kecamatan Banyuputih memiliki angka kepadatan penduduk yang masih berada dibawah 104 jiwa per $\mathrm{Km}^{2}$. Namun demikian jika ditinjau per desa, ternyata Desa Sumberejo mempunyai kepadatan penduduk terbesar yaitu 18.937 jiwa yang merupakan wilayah paling padat, sedangkan jumlah terkecil adalah Desa Banyuputih 4.826 jiwa.Lapangan pekerjaan yang paling diminati adalah di bidang pertanian. Wilayah ini sangat memungkinkan pengembangan pertanian melihat lebih dari 50\% penduduknya berusaha di bidang pertanian, baik sebagai petani tanaman pangan, petani nelayan, peternak maupun sebagai buruh tani.

Sarana prasarana pendidikan Kecamatan Banyuputih terdiri dari 20 unit TK, 29 unit SD, 9 unit SMP/MTs, 5 unitSMA/SMK, dan satu perguruan tinggi yang mengelola pendidikan sampai jenjang pascasarjana. Sarana kesehatan meliputi puskesmas induk 1 unit, puskesmas pembantu 5 unit, ponkesdes 2 unit, poskesdes 1 unit, dokter

Vol. 2 No. 2, Oktober 2020
Ummal Khoiriyah \&

Risma fahrul Amin | 366

gurnal Pengabdian Masyarakat 
umum 2 orang, dokter gigi 2 orang, mantri/perawat 25 orang, bidan 13 orang, laboratorium 1 unit, klinik sanitasi 1 unit dan puskesmas keliling 3 unit.Sedangkan posyandu terdapat 55 unit yang tersebar di semua desa di Kecamatan Banyuputih.

Hampir seluruh penduduk di Kecamatan Banyuputih memeluk agama Islam (99\%) sedangkan sisanya memeluk agama Kristen, Katholik, dan Hindu yang tersebar di 5 desa. Hal ini didukung adanya Pondok Pesantren Salafiyah Syafi'iyah Sukorejo dan sarana ibadah bagi umat Islam, diantaranya masjid sebanyak 28 buah, mushalla sebanyak 114 buah, dan surau sebanyak 90 buah serta pondok pesantren sebanyak 9 buah yang digunakan sebagai tempat untuk menggali dan mamperdalam ilmu agama Islam.

\section{Kondisi yang Diharapkan di Lokasi Pendampingan}

Secara umum kondisi dampingan yang diharapkan masyarakat pada program pengabdian kepada masyarakat ini adalah pemberdayaan ekonomi masyarakat berbasis Masjid. Oleh karenanya, secara umum pengabdian kepada masyarakat ini diharapkan, pertama, dapat membentuk Pusat Layanan Masyarakat berbasis masjid sebagai sarana pemberdayaan keluarga dan masyarakat untuk pengembangan SDM dan pengentasan kemiskinan. Sasaran utama pembentukan ini bukan semata-mata dengan tujuan pembentukan organisasi, tetapi

Vol. 2 No. 2, Oktober 2020
Ummal Khoiriyah \&

Risma fahrul Amin | 367

gurnal Pengabdian Masyarakat 
dimaksudkan agar keluarga muda, keluarga lansia, keluarga kaya dan keluarga miskin bisa bersilaturahmi dan saling peduli sesama.

Kedua, melalui pengabdian kepada masyarakat ini dapat terbentuknya kepengurusan melalui fasilitas yang diberikan atau diupayakan oleh pengabdi dilakukan melalui pemanfaatan potensi sumber daya yang ada di Kecamatan Banyuputih.

Ketiga, dapat tersusun rencana program dan kegiatan pembangunan yang kreatif dan inovatif berdasarkan human development atau Millennium Development Goals melalui pengembangan kemampuan keluarga dan masyarakat dengan mengembangkan program pembangunan yang dapat dilakukan oleh masyarakat secara mandiri.Hal itu untuk mengatasi permasalahan yang dihadapi masyarakat berdasarkan potensi, minat masyarakat dan kondisi penduduk sebagai sasaran pengabdian kepada masyarakat khususnya untuk menumbuhkan dan mengembangkan aktivitas ekonomi keluarga dan kewirausahaan berbasis masjid, terutama yang dilaksanakan oleh kaum perempuan, sehingga secara bertahap tidak ada lagi keluarga berpenghasilan dibawah standar upah minimum regional.

\section{Strategi Pelaksanaan}

Pusat Layanan Masyarakat dapat dibentuk di antara kalangan keluarga maupun antar keluarga, sehingga dapat memiliki basis pribadi

Vol. 2 No. 2, Oktober 2020
Ummal Khoiriyah \&

Risma fahrul Amin | 368

gurnal Pengabdian Masyarakat 
ataumemiliki basis kelompok.Program utama Pusat Layanan Masyarakat ini adalah pengentasan kemiskinan.Pengentasan kemiskinan diarahkan bukan untuk memberi uang, tetapi lebih ditonjolkan kepada pemberian pekerjaan, pemberian pelatihan, kewirausahaan, dll.Kewirausahaan misalnya dapat diawali dengan pembentukan koperasi dalam melakukan pembangunan usaha kecil.

Pusat Layanan Masyarakat adalah forum silaturahmi, advokasi, komunikasi, informasi, edukasi dan sekaligus bisa dikembangkan menjadi wadah koordinasi kegiatan penguatan fungsi-fungsi kekeluargaan secara terpadu. Penguatan fungsi-fungsi utama tersebut diharapkan memungkinkan setiap keluarga makin mampu membangun dirinya menjadi keluarga sejahtera, keluarga yang mandiri dan keluarga yang sanggup menghadapi tantangan masa depan dengan lebih baik.

Pusat Layanan Masyarakat merupakan gagasan baru guna menyambut anjuran pemerintah untuk membangun sumberdaya manusia melalui partisipasi keluarga secara aktif. Proses pemberdayaan itu diprioritaskan pada peningkatan kemampuan keluarga untuk bekerja keras mengentaskan kebodohan, kemalasan dan kemiskinan dalam arti yang luas. Sasaran kegiatan yang dituju adalah terselenggarakannya upaya bersama agar setiap keluarga mempunyai kemampuan melaksanakan delapan fungsi keluarga.

Vol. 2 No. 2, Oktober 2020
Ummal Khoiriyah \&

Risma fahrul Amin | 369

gurnal Pengabdian Masyarakat 
Pendekatan yang dapat digunakan dalam rangka pemberdayaan masyarakat untuk pengentasan kemiskinan adalah melalui pendekatan dualistik yakni dengan mengubah masyarakat dan mengubah lingkungan dalam pemecahan masalah masyarakat.

Pendekatan dualistik pada intinya merupakan pendekatan yang membahas bagaimana individu, kelompok ataupun komunitas berusaha mengontrol kehidupan mereka sendiri dan mengusahakan masa depan sesuai dengan keinginan mereka.

Masyarakat miskin merupakan kelompok masyarakat yang rentan dan lemah serta tidak memiliki kekuatan dan kemampuan untuk berdaya.Melalui upaya pemberdayaan masyarakat diharapkan mereka dapat memiliki kemampuan dan kekuatan untuk memenuhi kebutuhan pokok bagi mereka dan keluarganya sehingga terbebas dari kemiskinan.

Melalui upaya pemberdayaan diharapkan mereka juga dapat menjangkau sumber-sumber produktif yang memungkinkan bagi mereka untuk meningkatkan pendapatan, meningkatkan pengetahuan dan keterampilan, serta ikut berpartisipasi dalam proses pembangunan.

Salah satu faktor pendukung keberhasilan pemberdayaan masyarakat melalui adalah pendampingan. Pusat Layanan Masyarakat adalah sebuah pola baru dalam program pemberdayaan. Implementasi yang mampu menggerakkan masyarakat dan berlangsung secara

Vol. 2 No. 2, Oktober 2020
Ummal Khoiriyah \&

Risma fahrul Amin | 370

gurnal Pengabdian Masyarakat 
berkelanjutan memerlukan adanya peran pendampingan.Layanan ini merupakan konsep dalam pemberdayaan masyarakat dalam rangka membangun kemandirian, sekaligus ikut serta mengentaskan kemiskinan.

Pusat Layanan Masyarakat yang memperoleh pendampingan diharapkan memperlihatkan kinerja yang bagus, melahirkan banyak ide kreatif dalam program pemberdayaan dan pemanfaatan potensi lokal. Secara praktis bentuk pendampingan dapat dikembangkan dengan kreatif, apalagi pada zaman teknologi komunikasi yang semakin mudah diakses oleh setiap orang.Prinsipnya, pendampingan dilakukan untuk membantu Pusat Layanan Masyarakat untuk mencari solusi berbagai permasalahan yang mereka hadapi sehingga mereka mempunyai program kegiatan yang benar-benar sesuai kebutuhan dan dapat terlaksana dengan baik.

Agar kondisi yang menjadi target harapandalam program ini dapat dicapai secara maksimal, maka pihak pelaksana program atau pengabdimencanangkan beberapa strategi antara lain yaitu,program ini akan diarahkan kepada proses-proses interaksi untuk mengembangkan pemahaman tentang masalah yang dihadapi bersama dan opsi-opsi solusinya; pengabdi akan membantu masyarakat dampingan dalam memahami kompleksitas permasalahan yang ada; pengabdi membantu Ummal Khoiriyah \& Risma fahrul Amin | 371 
mengembangkan pemahaman bersama tentang permasalahan dan solusinya melalui komunikasi; pengabdi akan mendampingi prosesproses pengambilan keputusan bersama; pengabdi hanya sebatas sebagai fasilitator pengambilan keputusan secara partisipatif.

\section{Kajian Teori}

\section{Pengertian Masjid}

Masjid berarti tempat beribadah.Akar kata dari masjid adalah sajada dimana sajada berarti sujud atau tunduk.Kata masjid sendiri berakar dari bahasa Arab.Masjid berasal dari kata sajada yang artinya tempat sujud atau tempat menyembah Allah swt.Secara teknis sujud adalah meletakkan kening ke tanah.Secara maknawi, jika kepada Tuhan sujud mengandung arti menyembah, jika kepada selain Tuhan, sujud mengandung arti hormat kepada sesuatu yang dipandang besar atau agung.

Masjid merupakan instrumen pemberdayaan umat yang memiliki peranan sangat strategis dalam upaya peningkatan kualitas masyarakat. Namun hal itu harus didukung oleh menejemen pengelolaan masjid yang baik dan terpadu. Masjid digunakan sebagai pusat kegiatan dengan alasan bahwa sejak zaman Rasulullah masjid menjadi pusat pemberdayaan umat yang tidak terbatas perannya hanya pelaksanaan ibadah wajib seperti shalat. Di zaman Rasulullah masjid bisa berfungsi

Vol. 2 No. 2, Oktober 2020
Ummal Khoiriyah \&

Risma fahrul Amin | 372

gurnal Pengabdian Masyarakat 
sebagai halaqoh, yakni untuk mendiskusikan berbagai permasalahan umat bahkan menjadi bagian dari perumusan kegiatan politik. Peran masjid menjadi dinamis dan berfungsi mendorong tumbuhkembangnya keberdayaan umat. Mengacu pada tradisi kenabian tersebut sebenarnya masjid dapat berkembang lebih luas menjangkau pengayaan sumberdaya umat melalui bentuk-bentuk kegiatan yang bersinergi antara praktik-praktik keberagamaan dan kehidupan umat di sekitar masjid. ${ }^{4}$

Dilihat dari segi fungsinya, sebenarnya masjid tidak hanya merupakan tempat atau sarana melaksanakan ibadah shalat semata. Masjid juga bisa berfungsi sebagai pusat pemberdayaan berbagai aspek kehidupan masyarakat sebagaimana yang telah dicontohkan oleh Rasulullah SAW dalam kehidupanya.

Disamping itu juga, fungsi masjid dikaitkan dengan implementasi ajaran Islam meliputi fungsi imaniyah mendekatkan diri kepada Allah dengan berteologi yang benar, fungsi ubudiyah menjalankan ritual sesuai aturan agama, fungsi mu'amalah memberdayakan umat dalam berbagai aspek kehidupan, fungsi adab mu'asyarah bersosialisasi dan kerjasama yang harmonis dalam kehidupan, dan fungsi akhlaq atau berperilaku

${ }^{4}$ Mufidah Ch, dkk, Menjadi Sejahtera \& Mandiri Bersama Posdaya Masjid Kabupaten Malang (LP2M-UIN Maling Press, 2014), hlm.3.

Vol. 2 No. 2, Oktober 2020

Ummal Khoiriyah \&

Risma fahrul Amin | 373

gurnal Pengabdian Masyarakat 
yang baik untuk membangun peradaban. ${ }^{5}$

Untuk mempertegas fungsi dasar masjid, setidaknya dapat dikembangkan menjadi beberapa fungsi secara lebih rinci yaitu antara lain: fungsi keagamaan; fungsi sosial; fungsi psikologi; fungsi edukasi dan berdakwah; fungsi politik; fungsi pengobatan fisik dan mental; fungsi peradilan; fungsi komunikatif; fungsi estetis. ${ }^{6}$

Menurut Nazarudin Umar", Rasulullah saw tidak hanya menjadikan masjid sebagai tempat pelaksanaan ibadah khusus seperti shalat, dsb., melainkan juga menjadi-kannya sebagai sarana melakukan pemberdayaan umat. Pada masa Rasulullah SAW, masjid juga dijadikan tempat untuk pembinaan penyebaran agama Islam, tempat mengobati orang sakit, tempat mendamaikan orang-orang yang bertikai, tempat untuk mengatur strategi dalam latihan perang, dan juga tempat untuk manyampaikan pengumuman penting. Hal tersebut tentunya dapat menjadi acuan pengembangan peran dan fungsi masjid khususnya dalam bidang pendidikan sesuai dengan perkembangan ilmu pengetahuan dan teknologi guna mewujudkan

${ }^{5}$ Ahmad Sarwono, Masjid Jantung Masyarakat (yogyakarta: Izzan Pustaka, 2003), 4 .

${ }^{6}$ Asmawati, Pemberdayaan Fungsi Masjid Raya Darussasalm, Jurnal Studi Agama dan Masyarakat Vol. 10 No. 2 Desember 2013, 65.

${ }^{7}$ nasaruddinumar.org , masjid-dalam-sejarah-pembentukan-bangsaindonesia

Vol. 2 No. 2, Oktober 2020
Ummal Khoiriyah \&

Risma fahrul Amin | 374

gurnal Pengabdian Masyarakat 
masyarakat yang berdaya dan mandiri.

Kontowijoyo menyatakan keprihatinannya dalam bukunya "Muslim Tanpa Masjid" ia mengkritisi pandangan bahwa masjid dianggap menghambat kemajuan pembangunan. Generasi muslim lebih suka mengidentikkan dirinya dengan masjid dan umat. Diperlukan integrasi substantif yang mempertemukan antara ilmu keislaman dengan ilmu sosial budaya dan lainnya. Di satu sisi umat membutuhkan masjid untuk mengespresikan citarasa keagamaan,di sisilain masjid membutuhkan umat untuk memakmurkannya, sehingga terwujud simbiose mutualistik. ${ }^{8}$

\section{Penduduk dan Letak Geografis Masyarakat di Lokasi Pendampingan}

Dari tahun ke tahun jumlah penduduk mengalami pertambahan, walaupun pertambahannya masih relatif kecil, karena keberhasilan KB sampai ke pelosok desa mampu menekan pertumbuhan jumlah penduduk. Menurut hasil registrasi penduduk jumlah penduduk Kecamatan Banyuputih sebanyak 54.097 jiwa yang terdiri atas laki - laki sebanyak 26.838 jiwa dan perempuan sebanyak 27.259 jiwa. Jumlah penduduk wanita tampak lebih banyak daripada laki - laki,berikut data penduduk dari masing-masing desa se Kecamatan Banyuputih per 01

${ }^{8}$ A. Bachrun Rifa'i \& Moch. Fakhruroji, Manajemen Masjid Mengoptimalkan Fungsi Sosial Ekonomi Masjid (Bandung: Benang Merah Press, 2005), 97.

Vol. 2 No. 2, Oktober 2020

Ummal Khoiriyah \&

Risma fahrul Amin | 375

gurnal Pengabdian Masyarakat 
Maret 2011 :

Evaluasi dan perencanaan pembangunan sedikit banyak dipengaruhi oleh kuantitas dan kualitas penduduk suatu daerah. Untuk mengetahui perkembangan penduduk dapat dilakukan dengan melihat pertumbuhan dan kepadatan penduduk per $\mathrm{Km}^{2}$. Pertumbuhan penduduk diakibatkan oleh 4 komponen yaitu : kelahiran (natalitas ), Kematian ( Mortalitas ), Migrasi masuk dan migrasi keluar.

Wilayah Kecamatan Banyuputih masih tergolong kecamatan yang tidak padat penduduknya. Hal ini dapat dilihat dari angka kepadatan penduduk yang masih berada dibawah 104 jiwa per $\mathrm{Km}^{2}$. Namun agak berbeda jika ditinjau per desa, ternyata Desa Sumberejo mempunyai kepadatan penduduk terbesar yaitu 18.937 jiwa yang merupakan wilayah paling padat, sedangkan jumlah terkecil adalah Desa Banyuputih 4.826 jiwa.

Di Kecamatan Banyuputih lapangan pekerjaan yang paling diminati adalah di bidang pertanian. Wilayah ini sangat memungkinkan pengembangan pertanian melihat lebih dari 50\% penduduknya berusaha di bidang pertanian, baik sebagai petani tanaman pangan, petani nelayan, peternak maupun sebagai buruh tani.

Hampir seluruh penduduk di Kecamatan Banyuputih memeluk agama Islam ( 99\% ) sedangkan sisanya memeluk agama Katholik,

Vol. 2 No. 2, Oktober 2020
Ummal Khoiriyah \&

Risma fahrul Amin | 376

gurnal Pengabdian Masyarakat 
protestan, dan Hindu yang tersebar di 5 desa. Hal ini didukung adanya Pondok Pesantren Salafiyah Syafi'iyah Sukorejo dan sarana ibadah bagi umat Islam, diantaranya masjid sebanyak 28 buah, mushalla sebanyak 114 buah, dan surau sebanyak 90 buah serta pondok pesantren sebanyak 9 buah yang digunakan sebagai tempat untuk menggali dan mamperdalam agama Islam.

Jumlah Taman Kanak - Kanak di Kecamatan Banyuputih yang terdapat di 5 ( lima ) desa sebanyak 20 unit. Kecamatan Banyuputih tergolong kecamatan yang maju dan penduduknya memiliki antusias yang tinggi terhadap pendidikan. Hal ini didukung oleh sarana pendidikan yang cukup banyak. Sarana pendidikan SD sebanyak 29 unit, SMP/MTs 9 unit, SMA/SMK 5 unit, Diploma 3 unit dan perguruan tinggi sebanyak 1 unit.Pelayan kesehatan di Kecamatan Banyuputih meliputi puskesmas induk 1 unit, puskesmas pembantu 5 unit, Ponkesdes 2 unit, Poskesdes 1 unit, Dokter Umum 2 orang, Dokter Gigi 2 orang, Mantri / Perawat 25 orang, Bidan 13 orang, Laboratorium 1 unit, Klinik Sanitasi 1 unit dan puskesmas keliling 3 unit Sedangkan posyandu terdapat 55 buah yang tersebar di semua desa di Kecamatan Banyuputih.

\section{Dinamika Keilmuan}

Kecamatan Banyuputih merupakan daerah pedesaan memiliki Vol. 2 No. 2, Oktober 2020 Ummal Khoiriyah \& Risma fahrul Amin | 377 gurnal Pengabdian Masyarakat 
karakteristik kultur budaya masyarakat yang khas. 90\% masyarakatnya berbahasa madura selebihnya jawa dll. Banyaknya lembaga pendidikan dan pondok pesantren memberikan kontribusi positif pada sektor keagamaan masyarakat, didukung dengan fasilitas rumah ibadah semisal Masjid, Musholla yang dapat ditemui dimana saja.

Walaupun sebagaian besar masyarakat Banyuputih adalah petani dan nelayan namun kesadaran akan pentingnya pendidikan mulai tumbuh dan menjadi perhatian masyarakat, tingginya partisipasi masyarakat pada pendidikan setidaknya menjadi salah satu nilai akan perubahan pola pikir dan sikap. Majlis-majlis taklim mulai aktif dan menjadi wadah silaturrahim masyarakat disamping juga sebagai media mengaji, berdiskusi tentang ajaran-ajaran agama.

\section{Teori yang dihasilkan dari Pendampingan}

Pendampingan ini mengharuskan terciptanya sustainable livelihood yang merupakan cara berpikir dan bekerja untuk pembangunan yang berkembang secara evolusi dan dalam tujuan untuk mengefektifkan segala usaha-usaha mengakhiri kemiskinan dan keterbelakangan dari seluruh aspek kehidupan. Penghidupanakan berkelanjutan jika penghidupan yang ada memampukan orang untuk menghadapi dan pulih dari tekanan dan guncangan, memampukan orang untuk mengelola dan menguatkan kemampuan dan kepemilikan sumber daya

Vol. 2 No. 2, Oktober 2020
Ummal Khoiriyah \&

Risma fahrul Amin | 378

gurnal Pengabdian Masyarakat 
untuk kesejahteraannya, serta tidak menurunkan kualitas sumber daya alam yang ada. ${ }^{9}$

Penghidupan keberlanjutan iniberusaha mengidentifikasi hambatan-hambatan paling besar yang dihadapi dan peluang-peluang yang paling menjanjikan bagi masyarakat, terlepas dari mana asalnya (misalnya di sektor mana, pada wilayah mana atau tingkat apa, dari lokal sampai internasional). Penghidupan keberlanjutandibangun di atas pengertian atau definisi masyarakat sendiri mengenai hambatan dan peluang tersebut.Apabila memungkinkan, pendekatan ini selanjutnya bisa membantu masyarakat menyadari hambatan dan peluang tersebut. Pendekatan sustainablelivelihoods berusaha memahami dan belajar dari perubahan sehingga bisa mendukung pola-pola perubahan yang positif dan membantu menghilangkan pola-pola yang negatif. ${ }^{10}$

\section{Pembahasan}

\section{Pelatihan Budidaya Jamur Tiram}

\footnotetext{
${ }^{9}$ Sebastian Saragih, Jonatan Lassa, Afan Ramli, Kerangka Penghidupan Yang Berkelanjutan. TT: ttp://www.zef.de/module/register/media/2390_SLChapter1.pdf Hal.20

10 Sebastian Saragih, Jonatan Lassa, Afan RamliKerangka Penghidupan Yang Berkeanjutan. TT: http://www.zef.de/module/register/media/2390_SLChapter1.pdf Hal. 7-9

$$
\text { Vol. } 2 \text { No. 2, Oktober } 2020
$$

Ummal Khoiriyah \& 
Pelatihan budidaya jamur tiram dilaksanakan pada Minggu, 12 Juli 2018.Kegiatan ini dihadiri lebih dari 30 peserta dari perwakilan Pusat Layanan Masyarakat berbasis masjid se-Kecamatan Banyuputih.Hadir pula petugas Penyuluh Pertanian Lapangan (PPL) Kecamatan Banyuputih.

Pelatihan budidaya jamur tiram ini merupakan pelatihan yang dirancang oleh pendamping, Ummal Khoiriyah, M.HI, dan tim pelatih agar para peserta bisa belajar sekaligus praktek budidaya jamur tiram secara bertahap. Sehingga peserta bisa membudidayakan jamur tiram dengan baik dan benar. Pelatihan ini dipandu oleh tim pelatih yaitu pengusaha dan praktisi jamur tiram yang sudah berpengalaman dari Malang, Jawa Timur.

Gambar 4.1

Pendampingan dan Pelatihan Budidaya Jamur Tiram

Ummal Khoiriyah \&

Risma fahrul Amin | 380

gurnal Pengabdian Masyarakat 


\begin{tabular}{|ll|l|}
\hline ISSN & $: 2656-5161$ & Ots-sidanah \\
e-ISSN & $: 2686-0643$ & \\
\hline
\end{tabular}

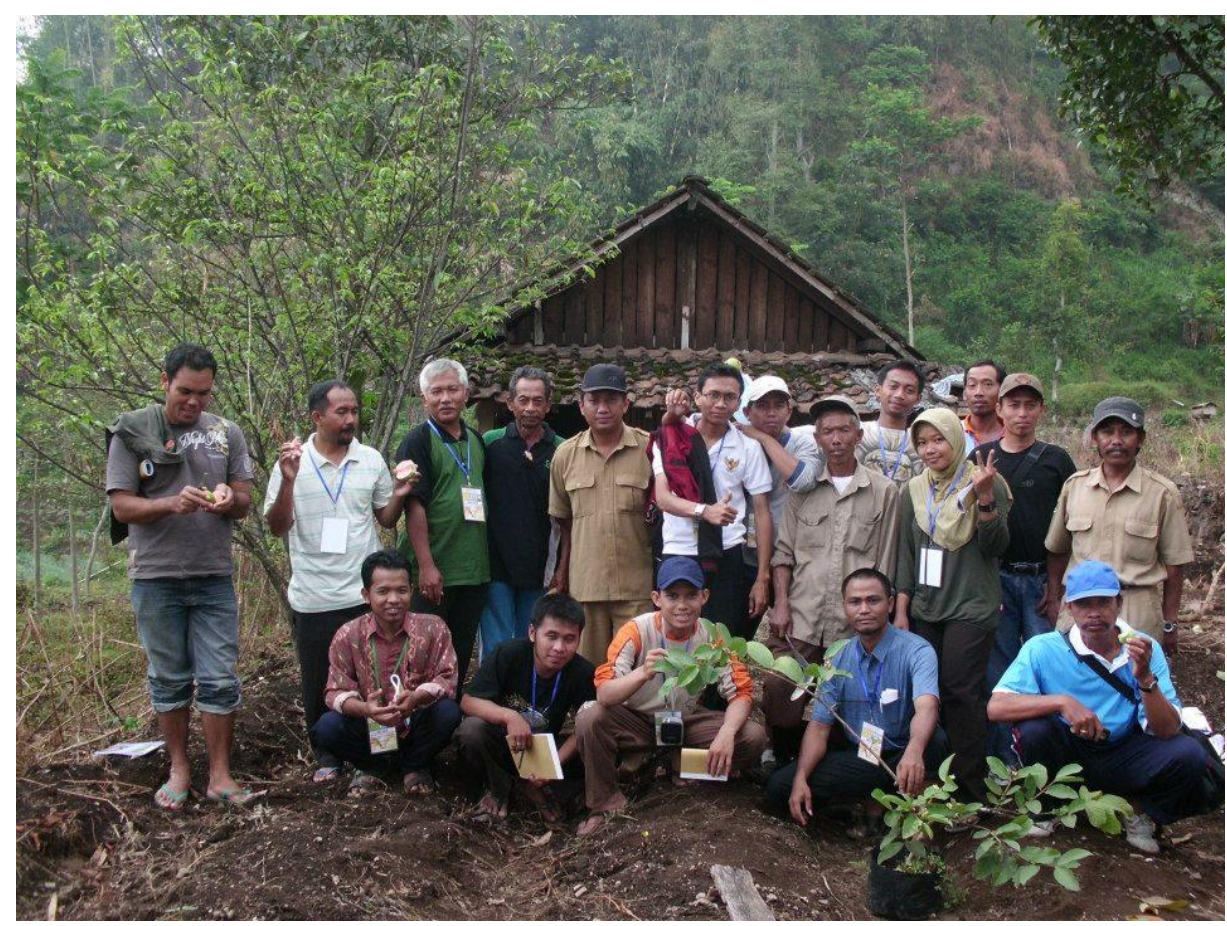

didesa Wonorejo, Kecamatan Banyuputih

Pelatihan dan pendampingan budidaya jamur tiram meliputi pemberian materi di serambi Masjid Al-Amin, Desa Wonorejo, dan praktek di alam terbuka pegunungan Desa Wonorejo, Kecamatan Banyuputih. Dalam pelatihan ini, para peserta bisa melihat secara langsung bagaimana proses budidaya jamur tiram. Harapannya, setelah pelatihan para peserta bisa belajar dan mempraktekkan budidaya jamur tiram dengan mudah. Dengan udara segar dan pemandangan asri di lokasi pelatihan, menjadi keasikan tersendiri bagi para peserta

$$
\text { Vol. } 2 \mathrm{No} .2 \text {, Oktober } 2020
$$

Ummal Khoiriyah \&

Risma fahrul Amin | 381

Qurnal Pengabdian Masyarakat 
perwakilan Pusat Layanan Masyarakat.

Pada kesempatan ini pendamping pengabdian kepada masyarakat, Ummal Khoiriyah, M.HI menyampaikan urgensi pelatihan budidaya jamur tiram ini bahwa jamur tiram merupakan salah satu bahan pangan yang memiliki manfaat berupa kandungan nutrisi yang tinggi. Selain itu permintaan pasar akan bahan pangan ini semakin meningkat dan produksi jamur ini tergolong mudah. Hal tersebut dapat dijadikan sebagai peluang usaha yang strategis bagi Pusat Layanan Masyarakat dalam rangka memberdayakan ekonomi umat.

Ummal Khoiriyah, M.HI menambahkan, terdapat beberapa cara budidaya jamur tiram salah satunya adalah menggunakan cara tradisional hanya dengan memanfaatkan kayu-kayu lapuk. Kayu yang sudah ditumbuhi oleh jamur tiram tidak bisa bertahan lama karena nutrisi yang terdapat di dalam kayu akan semakin habis dan jamur tidak dapat lagi tumbuh. Oleh sebab itu dilakukan pelatihan budidaya jamur tiram kepada peserta dari perwakilan Pusat Layanan Masyarakat sebagai calon produsen sehingga para peserta dapat memahami proses dan produksi jamur tiram dengan baik dan benar.

Materi yang disampaikan oleh tim pelatih antara lain mengenai, pengenalan budidaya jamur tiram untuk pemula; teori pembuatan kumbung; praktek pembuatan bibit jamur tiram dari F0-F2; praktek

Vol. 2 No. 2, Oktober 2020
Ummal Khoiriyah \&

Risma fahrul Amin | 382

gurnal Pengabdian Masyarakat 
pembuatan media tanam; praktek pembuatan baglog; praktek budidaya (perawatan dan panen) dan pengenalan pasca panen dan olahan jamur tiram.

Setelah pemberian materi, dilakukan praktek pembuatan medium dari bibit F0 hingga baglog produksi.Medium yang telah dibuat dilakukan sterilisasi menggunakan autoclave. Pada kegiatan ini juga peserta diajarkan cara menggunakan autoclave yang baik dan benar. Setelah itu peserta diajarkan teknik aseptis yang menjadi prinsip dasar dari proses penanaman jamur atau inokulasi jamur pada media. Kegiatan dilanjutkan dengan praktik inokulasi jamur dari bibit F0 hingga bibit F3 dan inokulasi pada medium baglog produksi.Kegiatan diakhiri dengan diskusi bersama narasumber.

"Pekerjaan budidaya jamur tiram memerlukan ketekunan dan tidak dapat diperoleh hasil yang instan sehingga peserta dari Pusat Layanan Masyarakat harus solid dan konsisten untuk dapat bertahan hingga hasil yang diharapkan," kata Hartono, S.P., petugas Penyuluh Pertanian Lapangan (PPL) Kecamatan Banyuputih.

\section{Pembinaan Usaha Jamur Tiram}

Salah satu usaha pertanian yang sangat prospektif dan potensial untuk dikembangkan di masyarakat adalah usaha budidaya jamur tiram (Pleurotus ostreatus), karena alasan mendasar antara lain, daya serap

Vol. 2 No. 2, Oktober 2020
Ummal Khoiriyah \&

Risma fahrul Amin | 383

gurnal Pengabdian Masyarakat 
pasar sangat tinggi dan semakin meningkat; kemungkinan stagnasi pasar sangat kecil karena merupakan konsumsi masyarakat sehari-hari; bahan baku mudah diperoleh dan murah; proses pemeliharaan tergolong mudah; tidak memerlukan lahan yang luas; budidaya jamur tiram tidak mengenal musim sehingga dapat menghasilkan keuntungan terus menerus sepanjang tahun; jamur tiram merupakan pangan alternatif yang lezat, sehat dan bergizi tinggi; tidak menimbulkan pencemaran lingkungan; baglog bekas media tanam dapat digunakan untuk pupuk kolam ikan, campuran pakan ikan, campuran pakan ternak, media memelihara cacing dan dapat dijadikan pupuk kompos.

Hasil produksi usaha Jamur Tiram di Pusat Layanan Masyarakat berbasis masjid se-Kecamatan Banyuputih sampai bulan Juli (Juli sampai Oktober 2018) memberikan prospek menggembirakan. Pada bulan Juli sampai Agustus dilakukan persiapan baik bahan maupun manajemen. Renovasi dan penambahan kapasitas kumbung ditingkatkan, disiapkan rak baglog, alat sterilisasi baglog, alat pengaduk bahan baglog. Salah satu Pusat Layanan Masyarakat yang menjadi percontohan di Desa Banyuputh memiliki green house yang bisa digunakan sebagai ruang inokulasi. Pada September 2018 sarana dan prasarana produksi jamur tiram sudah tersedia. Baglog yang dihasilkan 1.000-1.250 baglog per minggu dengan bahan pembuatan baglog

Vol. 2 No. 2, Oktober 2020
Ummal Khoiriyah \&

Risma fahrul Amin | 384

gurnal Pengabdian Masyarakat 
berkisar Rp 450.000 untuk setiap Pusat Layanan Masyarakat. Jamur yang dihasilkan berjumlah lebih kurang 25-30 kg per minggu.
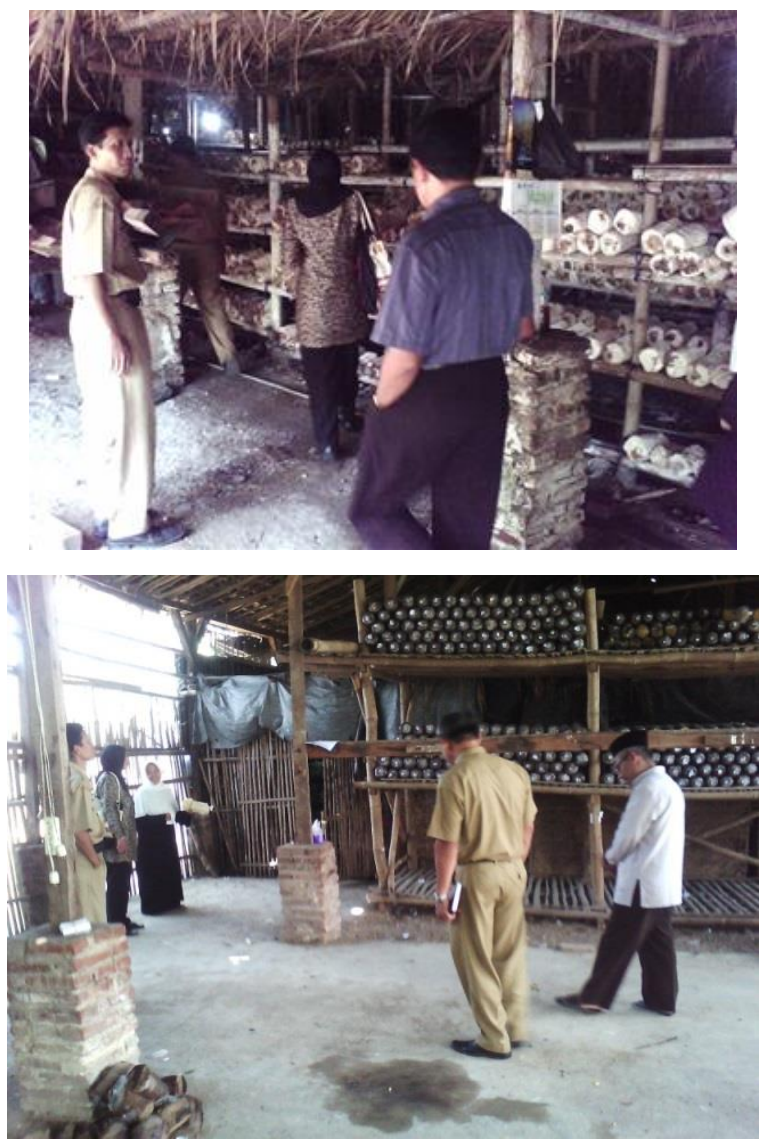

Gambar 4.2. Pendampingan dan monitoring usaha jamur tiram di kumbung Pusat Layanan Masyarakat berbasis masjid di Desa Banyuputih

Selain pendapatan dari jamur segar, usaha ini memberikan

Vol. 2 No. 2, Oktober 2020
Ummal Khoiriyah \&

Risma fahrul Amin | 385

gurnal Pengabdian Masyarakat 
dampak kepada masyarakat sekitar masjid yaitu dengan adanya pelatihan-pelatihan. Selain budidaya jamur yang bernilai ekonomi, pelatihan sekaligus praktek pemasaran produk jamur bagi jamaah masjid, merupakan good practices yang langsung bisa dilaksanakan dan langsung bisa dirasakan manfaatnya oleh masyarakat . Pengolahan produk olahan jamur juga menjadi materi pelatihan Pusat Layanan Masyarakat berbasis masjid. Limbah baglog diolah menjadi kompos dan dijual seharga Rp 8000 per kemasan kecil.

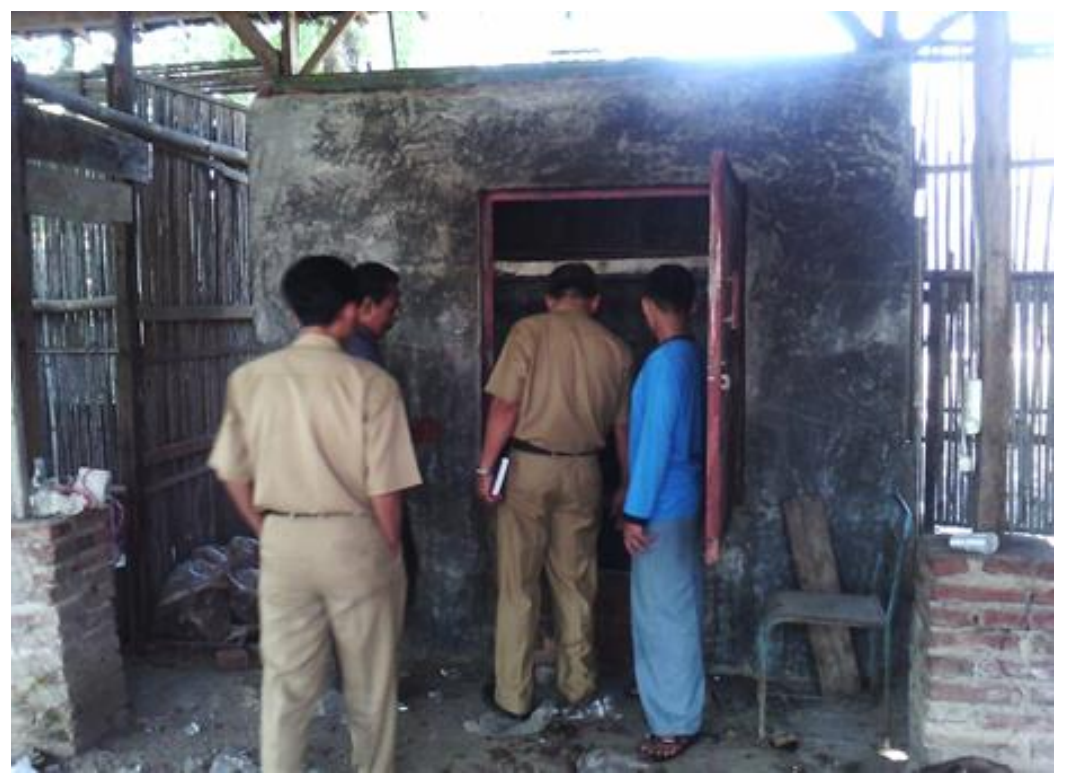

Gambar 4.3. Pengecekan daya tampung oven untuk produksi baglog oleh petugas Penyuluh Pertanian Lapangan (PPL) Kecamatan Banyuputih

Vol. 2 No. 2, Oktober 2020
Ummal Khoiriyah \&

Risma fahrul Amin | 386

gurnal Pengabdian Masyarakat 


\section{Pendampingan Pemasaran Produk Olahan Jamur Tiram}

Usaha budidaya jamur tiram merupakan usaha yang cukup menjanjikan di Situbondo. Usaha ini dilakukan dengan adopsi teknologi sederhana dalam teknik budidaya jamur. Jamur tiram yang terdapat di swalayan atau mall umumnya didatangkan dari luar Situbondo, sehingga stok jamur tiram di pasaran sangat sedikit. Dengan usaha budidaya dan produksi jamur tiram pada kegiatan bersama Pusat Layanan Masyarakat berbasis masjid se-Kecamatan Banyuputih ini diharapkan dapat menekan harga jual jamur tiram yang relatif tinggi, tanpa mengesampingkan aspek profit dari usaha tersebut.

Pangsa pasar jamur di Situbondo relatif tinggi dengan harga yang relatif tinggi pula. Sebagai pembanding harga jamur tiram di pasaran hasil survei harga rata-rata jamur yang dijual di Situbondo per Mei 2018 adalah Rp 20.000 - Rp 25.000,- per Kg.

Sedikitnya petani jamur, stok jamur yang terbatas dan permintaan jamur yang tinggi menyebabkan harga jamur di Situbondo relatif tinggi. Hal ini menjadikan usaha budidaya jamur tiram menjadi sangat potensial. Hasil produksi usaha jamur tiram di Pusat Layanan Masyarakat berbasis masjid se-Kecamatan Banyuputih disalurkan ke pasar tradisional dan swalayan. Model pemasaran yang digunakan adalah agen distributor dan kerja sama dengan beberapa mall atau

Vol. 2 No. 2, Oktober 2020
Ummal Khoiriyah \&

Risma fahrul Amin | 387

gurnal Pengabdian Masyarakat 
swalayan, pemerintah, dan media massa.
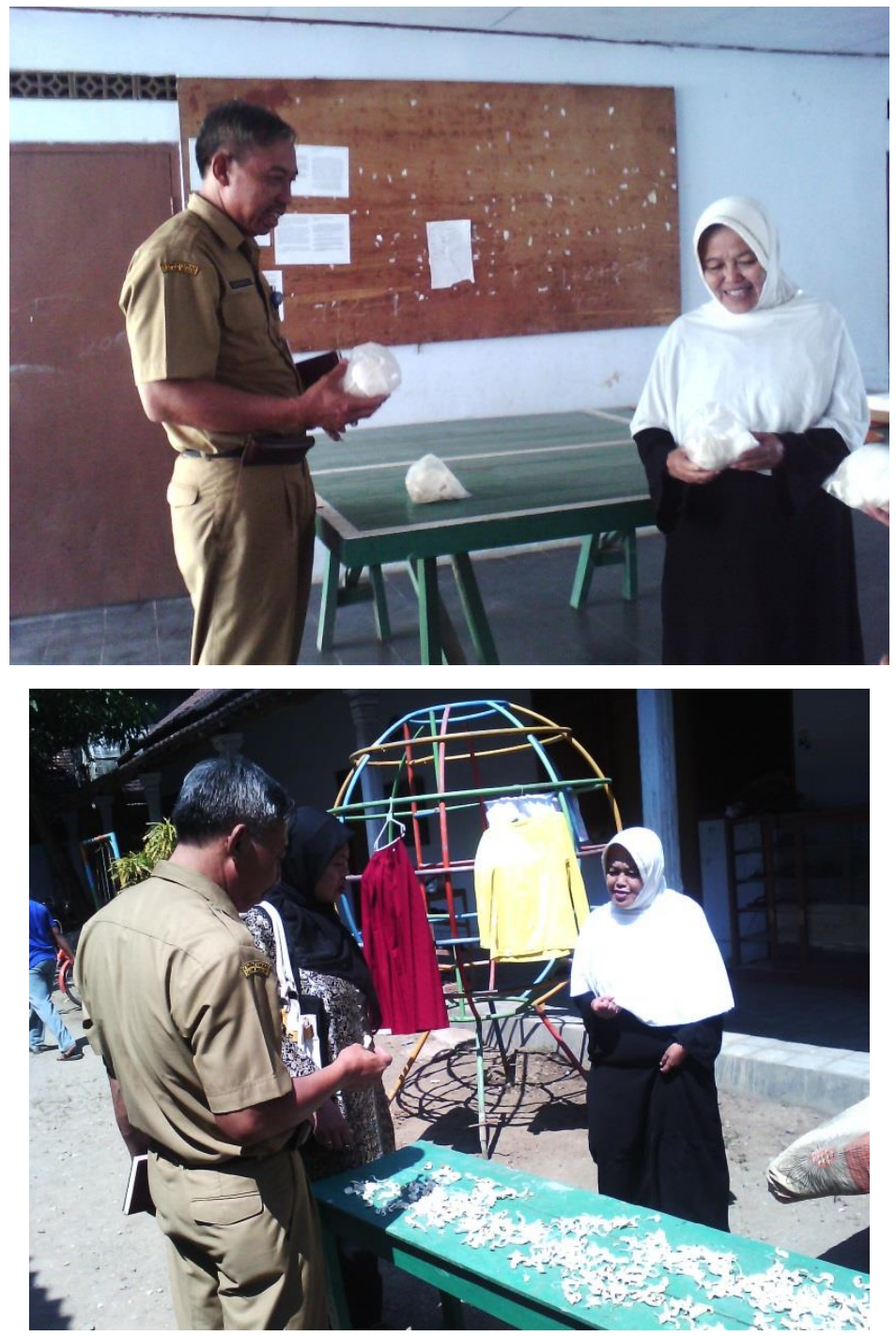

Gambar 4.4.pengolahan dan pengemasan jamur tiram di kumbung Pusat Layanan Masyarakat berbasis masjid di Desa Banyuputih

Vol. 2 No. 2, Oktober 2020
Ummal Khoiriyah \&

Risma fahrul Amin | 388 gurnal Pengabdian Masyarakat 


\section{Follow Up}

Pengabdian ini telah berjalan efektif membantu pemberdayaan ekonomi masyarakat, serta telah terintegrasi dengan Program Pendampingan pada Masyarakat Posdaya Berbasis Masjid.Penguatan ekonomi masyarakat berbasis masjid tetap menjadi fokus utama selain merambah pada fungsi-fungsi lain yang dapat terintegrasi dengan masjid.

\section{Kesimpulan}

Dari hasil program pengabdian pada masyarakat ini, dapat disimpulakan bahwa upaya yang telah dilakukan oleh takmir masjid dalam menjalankan Pusat Layanan Masyarakat berbasis masjid adalah dengan menjalankan usaha budidaya jamur yang meliputi proses produksi, quality control, dan pemasaran.

\section{Daftar Pustaka}

Ahmad Sarwono, Masjid Jantung Masyarakat, Yogyakarta: Izzan Pustaka, 2003.

Asmawati, Pemberdayaan Fungsi Masjid Raya Darussasalm, Jurnal Studi Agama dan Masyarakat Vol. 10 No. 2 Desember 2013 .

Bachrun Rifa'i \& Moch. Fakhruroji, Manajemen Masjid Mengoptimalkan

Vol. 2 No. 2, Oktober 2020
Ummal Khoiriyah \&

Risma fahrul Amin | 389

gurnal Pengabdian Masyarakat 
Fungsi Sosial Ekonomi Masjid, Bandung: Benang Merah Press, 2005. Dirjen Kelembagaan Agama Islam Depag RI, 2004: 16.

Hajma, Tajuddin."Manajemen Kemasjidan”. Makalah yang disajikan selama proses perkuliahan berlangsung di Universitas Islam Negeri Alauddin Makassar, Kampus II Samata-Gowa 2014.

Instruksi Presiden Republik Indonesia No. 3 Tahun 2010 Tentang Program Pembangunan Yang Berkeadilan. 2010.

Mufidah Ch, dkk, Menjadi Sejahtera \& Mandiri Bersama Posdaya Masjid Kabupaten Malang, LP2M-UIN Maling Press, 2014.

Sebastian Saragih, Jonatan Lassa, Afan Ramli, Kerangka penghidupan Yang Berkelanjutan.TT:ttp://www.zef.de/module/register/media/2390_SL Chapter1.pdf.

nasaruddinumar.org > masjid-dalam-sejarah-pembentukan-bangsaindonesia

Ummal Khoiriyah \&

Risma fahrul Amin | 390

gurnal Pengabdian Masyarakat 